\title{
Pembuatan dan Karakterisasi Membran Komposit sPEEK-PVA dengan Bahan Isian Grafena Oksida untuk Sel Bahan Bakar Methanol
}

\section{Preparation and Characterization of sPEEK-PVA Composite Membranes with Graphene Oxide as filler for Direct Methanol Fuel Cells}

\author{
Elisa Putri Nastiti, Nur Hidayati*
}

Program Studi Teknik Kimia, Fakultas Teknik, Universitas Muhammadiyah Surakarta

\author{
Jl. A. Yani Tromol Pos 1 Pabelan, Kartasura, Surakarta Indonesia
}

\section{Artikel histori : \\ Diterima 9 Septermber 2020 Diterima dalam revisi 26 Oktober 2020 Diterima 26 Oktober 2020 Online 31 Oktober 2020}

\begin{abstract}
ABSTRAK: Direct Methanol fuel Cell (DMFC) merupakan teknologi sel bahan bakar yang mengubah energi kimia menjadi energi listrik secara langsung. Polieter eter keton tersulfonasi (sPEEK) berpotensi sebagai proton exchange membrane. Modifikasi sPEEK dengan poli vinil alkohol (PVA) dan penambahan grafena oksida (GO) diharapkan dapat mengurangi methanol cross over. Penelitian dirancang untuk mengkaji karakteristik membran komposit sPEEKPVA dengan menggunakan variabel bebas variasi GO 2,5-10\% w/w. Hasil pengujian menunjukkan water uptake pada rentang 20-33\% swelling degree pada rentang 10-17,5\%, kapasitas penukar ion sebesar 0,59-0,75 meq/g, dan permeabilitas metanol sebesar 2,82-4,2 $\mathrm{x} 10^{-6} \mathrm{~cm}^{2} / \mathrm{s}$. Karakter yang ditunjukkan sepadan dengan karakter Nafion dan berpotensi untuk dikembangkan karena lebih unggul dalam hal harga bahan bakunya.
\end{abstract}

Kata Kunci: DMFC; membran komposit; sPEEK,PVA; Grafena Oksida

\begin{abstract}
Direct Methanol Fuel Cell (DMFC) is a fuel cell technology that convert chemical energy into electrical energy directly. Sulfonated polyether ether ketones (sPEEK) have potential as proton exchange membranes. Modification of SPEEK with poly vinyl alcohol (PVA) and adding graphene oxide (GO) is expected to reduce methanol cross over. This study was designed to examine the characteristics of the SPEEK-PVA composite membrane using the independent variable variation of GO $2.5-10 \% \mathrm{w} / \mathrm{w}$. The results showed that water uptake in the range of $20-33 \%$, swelling degree in the range of $10-17.5 \%$, the ion exchange capacity was $0.59-0.75 \mathrm{meq} / \mathrm{g}$, and the methanol permeability was $2.82-4.2 \times 10^{-6} \mathrm{~cm}^{2} / \mathrm{s}$. The characters shown are comparable with Nafion's characters and have the potential to be developed because they are superior in terms of raw material prices.
\end{abstract}

Keywords: DMFC; composite membranes; sPEEK,PVA; Graphene Oxide

\section{Pendahuluan}

Fuel cell atau sel bahan bakar merupakan teknologi elektrokimia yang mengubah energi kimia menjadi energi listrik (Ettihir et al., 2016), sedangkan Direct Methanol Fuel Cells (DMFC) atau sel bahan bakar metanol merupakan sel bahan bakar yang mengubah secara langsung metanol melalui reaksi elektrokimia menjadi listrik. DMFC dianggap sebagai teknologi yang lebih ramah lingkungan, tahan lama dan merupakan rancangan sel yang kompak (Neburchilov et al., 2007). Proton Exchange Membrane (PEM) merupakan komponen kunci DMFC karena sifatsifat PEM mempengaruhi kinerja DMFC. Pada umumnya PEM yang digunakan adalah Nafion, karena memiliki konduktivitas proton tinggi, kestąbilan kimia dan termal yang baik (Kusworo et al. 2013). Namun, Nafion memiliki keterbatasan seperti tingginya biaya produksi dan metanol cross-over (permeabilitas metanol) yang menyebabkan hilangnya sebagian bahan bakar methanol dan menyebabkan laju reaksi di katoda menjadi lebih lambat, sehingga kinerjanya juga akan melambat (Mahatmanti et al., 2017).

Berbagai hidrokarbon berbasis polimer sulfonasi telah disintesis dan digunakan sebagai membran elektrolit dalam sel bahan bakar salah satunya yaitu polieter eter keton (PEEK) (Guo et al., 2013), PEEK disulfonasi terlebih dahulu menjadi sPEEK. sPEEK memiliki sifat ketahanan terhadap zat kimia yang baik, stabilitas mekanik, hidrofilik dan stabilitas termal yang baik serta harganya terjangkau (Mahajan and Ganesan 2010). Beberapa upaya dilakukan untuk memodifikasi sPEEK dengan polimer lain salah 
satunya dengan Polivinyl alkohol (PVA). PVA digunakan karena memiliki gugus $-\mathrm{OH}$ yang mudah dikombinasikan (Sahin, 2018). Pada stukturnya, gugus sulfonat sPEEK akan berinteraksi dengan gugus polimer dari PVA kemudian akan menghasilkan membran yang memiliki stabilitas termal yang jauh lebih baik serta kekuatan untuk menghalangi methanol (methanol cross over) yang tinggi (Yang, 2008).

Upaya meningkatkan sifat-sifat membran sPEEK termasuk sifat kimia dan mekanik dilakukan dengan memodifikasi dengan menambahkan nano material seperti oksida anorganik, zeolit, pengisi konduktif proton (Rahman et al., 2012). Salah satu bahan isian yang bisa digunakan untuk membran adalah grafena oksida (GO). GO merupakan bahan organik yang banyak digunakan untuk beberapa aplikasi karena mempunyai sifat termal dan mekanik yang sangat baik (Santosa et al., 2015), hal ini dikarenakan GO meiliki gugus fungsi beroksigen ( $\mathrm{HAI}, \mathrm{OH}$ dan $\mathrm{COOH}$ ) dalam stukturnya, yang berpartisipasi dalam pembentukan saluran ikatan hidrogen satu dimensi untuk tranport proton (Reyes-Rodriguez et al. 2017). GO merupakan insulator elektronik dengan konduktivitas diferensial. Membran yang digabungkan dengan GO memberikan nilai konduktivitas proton yang tinggi, hal ini dikarenakan adanya ikatan hidrogen pada GO. Gugus fungsi seperti asam karboksilat dan ikatan hidrogen antar molekul memberikan tambahan jalur untuk memperbanyak proton (Santosa et al., 2015).

Penelitian ini bertujuan untuk mengkaji pengaruh penambahan grafena oksida pada membran sPEEK-kitosan seperti water uptake, swelling degree, kapasitas penukar ion dan permeabilitas metanol pada membran.

\section{Metode Penelitian}

Bahan-bahan yang digunakan adalah PEEK diimpor dari China, poli vinil alkohol (PVA) dibeli dari toko kimia lokal, asam sulfat dari Mallinckrodt, asam asetat dan dimethylacetamide (DMAC) dari Merck, GO dipersiapkan dari karbon berukuran nano. Penelitian dilakukan di laboratorium Program Studi Teknik Kimia, Universitas Muhammadiyah Surakarta. Penelitian menggunakan rancangan acak lengkap satu faktor yaitu dengan variabel bebas persentase grafena oksida dalam membran, variabel terikat karakteristik membran, dan varibel kontrol rasio sPEEK-PVA.

\subsection{Sintesa Grafena Oksida}

Sebanyak 3 gram $\mathrm{NaNO}_{3}$ dan $140 \mathrm{~mL}$ asam sulfat dimasukkan dalam gelas beker yang diletakkan dalam wadah yang diberi es. Larutan dipertahankan pada suhu di bawah $20^{\circ} \mathrm{C}$ agar tidak terjadi reaksi spontan. Kemudian 3 gram grafit dan 15 gram $\mathrm{KMNO}_{4}$ ditambahkan perlahanlahan dan diaduk selam 2 jam. Kemudian gelas beker dijaga pada suhu ruang selama 24 jam untuk terjadi reaksi oksidasi. Selanjutnya ditambah $100 \mathrm{~mL}$ air suling dan diaduk selama 1 jam. Kemudian larutan ditambah $10 \mathrm{~mL} \mathrm{H}_{2} \mathrm{O}_{2}$. Larutan kemudian dicuci dengan $\mathrm{HCl} 1 \mathrm{M}$ dan air aquades sampai mencapai $\mathrm{pH}$ netral. Grafena oksida dipanaskan pada suhu $80^{\circ} \mathrm{C}$.

\subsection{Sulfonasi PEEK}

Polieter eter keton disulfonasi dengan dilarutkan dengan asam sulfat pada suhu $60^{\circ} \mathrm{C}$ selama $4 \mathrm{jam}$. Kemuadian larutan dituang kedalam air es hingga polimer berwarna putih dan dicuci dengan air aquades hingga $\mathrm{pH}$ air mencapai 7. sPEEK kemudian dikeringkan sebelum digunakan pada tahap seanjutnya.

\subsection{Pembuatan membran komposit}

Membran dipersiapkan dengan membuat larutan sPEEK dan larutan PVA. Sebanyak 2 gram sPEEK dilarutkan pada 100 $\mathrm{mL}$ dimetil acetamida dan 1 gram PVA pada $100 \mathrm{~mL}$ air. Larutan sPEEK dan larutan PVA untuk membuat membran dengan perbandingan 20:80 \%wt. GO ditambahkan pada larutan dengan variasi $(2,5-10) \%$ wt dan diultrasonik selama 30 menit, setelah itu diaduk kembali selama 5 menit. Kemudian, dilakukan pencetakan dengan menuangkan campuran pada pelat kaca. Pelat dipanaskan pada suhu $60^{\circ} \mathrm{C}$ selama 24 jam. Kemudian membran dipanaskan didalam oven selama 1 jam pada suhu $110^{\circ} \mathrm{C}$ agar terjadi hubungan silang antar molekul.

\subsection{Analisa Water Uptake dan Swelling Degres}

Water uptake (WU) diukur berdasarkan perbedaan berat basah dan kering membran. Membran ditimbang untuk diperoleh berat kering $\left(W_{\text {dry }}\right)$. Untuk memperoleh berat basah ( $W_{\text {wet }}$ ) dengan merendam membran pada air suling selama 48 jam. Sedangkan swelling degree (SD) dapat dihitung sebagai perubahan ukuran panjang membran kondisi kering $\left(L_{\mathrm{dry}}\right)$ dan basah $\left(L_{\mathrm{wet}}\right)$.

Perhitungan water uptake:

$$
\begin{aligned}
& \text { Water Uptake }(\%)=\frac{W_{w e t}-W_{d r y}}{W_{d r y}} \times 100 \% \\
& \text { Swelling Ratio }(\%)=\frac{L_{w e t}-L_{d r y}}{L_{d r y}} \times 100 \%
\end{aligned}
$$

\subsection{Analisa permeabilitas metanol melewati membran}

Permeabilitas metanol diukur dengan menggunakan dua gelas yang saling terhubung dan membran diletakkan di antara keduanya. Gelas (A) diisi dengan $100 \mathrm{~mL}$ metanol 3M dan gelas (B) diisi dengan $100 \mathrm{ml}$ aquades. Larutan dari masing-masing gelas diaduk secara terus menerus selama pengukuran dengan rentang waktu untuk pengukuran selama 1 jam. Konsentrasi metanol dalam gelas B diukur sebagai fungsi waktu dengan menggunakan refraktometer. Indeks bias kemudian diobservasi dibandingkan dengan nilai dari kurva kalibrasi. Konsentrasi metanol dalam gelas B sebagai fungsi waktu mengikuti hukum pertama Fick dengan mengasumsikan $C_{B} \ll C_{A}$; sehingga $C_{A}$ dapat dianggap konstan

$V_{B} \frac{d C_{B}(t)}{d t}=\frac{A}{L} D K C_{A}$

dimana $C_{A}$ dan $C_{B}$ adalah konsentrasi metanol dalam gelas $\mathrm{A}$ dan $\mathrm{B}$; A dan $\mathrm{L}$ adalah luas penampang membran dan ketebalan membran; D dan K adalah difusivitas metanol dan koefisien partisi antara membran dengan larutan. D 
diasumsikan konstan di seluruh permukaan membran dan $\mathrm{K}$ tidak dipengaruhi oleh konsentrasi. Produk dari DK merupakan permeabilitas membran $(\mathrm{P})$ yang dihitung dari kemiringan $\mathrm{C}_{\mathrm{B}}$ terhadap waktu

$P=\frac{C_{B}(t)}{t} \frac{V_{B} L}{C_{A} A}$

\subsection{Kapasitas Penukar Ion (IEC)}

Kapasitas Penukar Ion (IEC) diukur dengan metode titrasi. Membran kering ditimbang $\left(\mathrm{W}_{\mathrm{dry}}\right)$ direndam dalam larutan $\mathrm{NaCl}$ pada suhu ruang selama 48 jam. Larutan kemudian dititrasi dengan $0,01 \mathrm{~N}$ larutan $\mathrm{NaOH}$ menggunakan indikator phenolphthalein sebanyak 3 tetes.

$I E C=\frac{C_{\mathrm{NaOH}} \times V_{\mathrm{NaOH}}}{W_{\text {dry }}}$

\section{Hasil dan Pembahasan}

Dalam artikel ini, membran yang dibuat dengan perbandingan sPEEK-PVA 80:20, membran yang dihasilkan mempunyai ketebalan sekitar 45-60 $\mu \mathrm{m}$.

\subsection{SPEEK-PVA-GO}

Paramater water uptake (WU) digunakan untuk mengetahui kandungan air didalam membran, karena keberadaan air dan gugus sulfonat dalam membran digunakan untuk memfasilitasi terjadinya transfer proton, selain itu kemampuan membran menyerap air berhubungan dengan konduktivitas ionik dan stabilitas mekaniknya (Hidayati et al., 2015). Gambar 1. menunjukkan hubungan antara kandungan grafena oksida dengan water uptake membran.

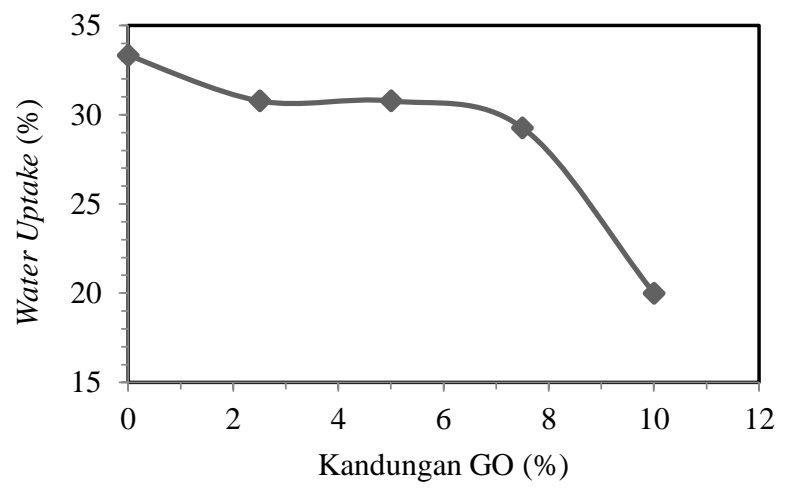

Gambar 1. Hubungan sifat water uptake dengan persentase grafena oksida dalam membran sPEEK

Membran sPEEK-PVA dengan bahan isian grafena oksida (GO) dipersiapkan untuk menurunkan kemampuan membran dalam menyimpan air. Hasil pengujian water uptake menunjukkan penurunan WU dari 33,3\% (tanpa GO) menjadi 20\% dengan kandungan GO 10\%. Penelitian lain dengan menggunakan membran PVA-kitosan-grafena oksida menunjukkan kecenderungan yang sama, nilai water uptake sebesar 26,3\% ditunjukkan dengan kandungan GO $10 \%$ (Shaari and Kamarudin, 2018).

Swelling degree merupakan parameter perubahan ukuran pada polimer yang dapat mempengaruhi kinerja dari membran, dapat dilihat dari kerapatan stuktur polimernya (Heo et al., 2013). Gambar 2. menunjukkan hubungan antara swelling degree dengan kandungan grafena oksida dalam membran.

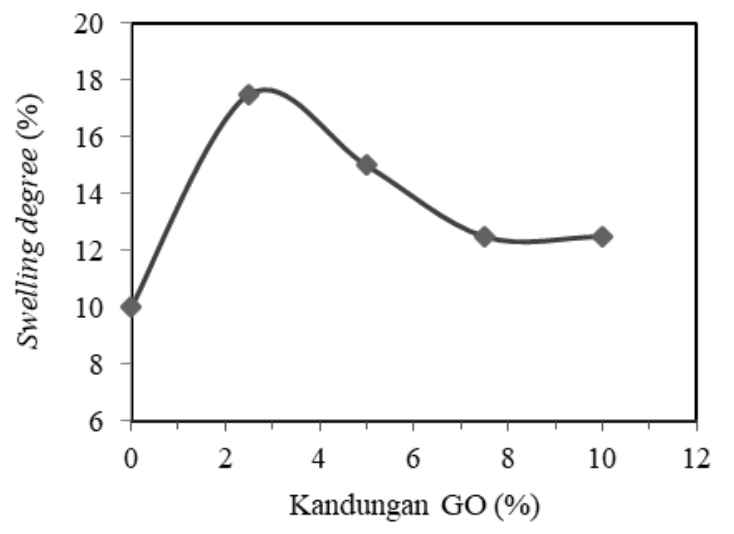

Gambar 2. Hubungan swelling degree dengan persentase grafena oksida dalam membran sPEEK

Membran sPEEK-PVA tanpa bahan isian GO menghasilkan nilai sweeling degree sebesar 10\%, sedangkan dengan konsentrasi GO 2,5\%-10\% swelling degree bervariasi dari $17,5 \%$ sampai $12,5 \%$. Penelitian sebelumnya pada membran dengan komposisi yang sama dengan konsentrasi penggunaan sPEEK-PVA-GO berbeda memiliki nilai swelling degree sebesar 18\% - 25\% (Reyes-Rodriguez et al., 2017). Nilai swelling menunjukkan kemampuan membran untuk mengadsorpsi pelarut yang dapat merubah struktur pori-pori dari membran dan dapat merepresentasikan fleksibilitas dan kekuatan dari membran (Shaari and Kamarudin, 2018).

\subsection{Permeabilitas Metanol}

Permeabilitas metanol merupakan ukuran yang digunakan untuk mengetahui banyaknya metanol yang melewati membran karena dapat mempengaruhi kinerja elektrokatalitik di katoda (Mahatmanti et al., 2017). Gambar 3. Menunjukkan hubungan antara permeabilitas metanol dengan kandungan grafena oksida.

Permeabilitas metanol memiliki korelasi dengan nilai swelling degree, penurunan nilai swelling degree pada penambahan bahan isian, berbanding terbalik dengan nilai permeabilitas metanol yang mengalami peningkatan. Nilai permeabilitas pada konsentrasi GO 2,5\%-10\% berkisar pada $2,82 \times 10^{-6} \mathrm{~cm}^{2} / \mathrm{s}-4,2 \times 10^{-6} \mathrm{~cm}^{2} / \mathrm{s}$. Sedangkan pada membran tanpa GO memiliki nilai cukup tinggi sekitar $4,0 \times 10^{-6} \mathrm{~cm}^{2} / \mathrm{s}$ mungkin dikarenakan metanol tidak mengalami hambatan yang berarti. Pada penelitian sebelumnya dilaporkan bahwa membran antara sPEEK dan Nafion 53 memiliki nilai antara $1,16 \times 10^{-6} \mathrm{~cm}^{2} / \mathrm{s}-9,09 \times 10^{-7} \mathrm{~cm}^{2} / \mathrm{s}$ serta sPEEK dan Nafion 63 antara $1,40 \times 10^{-6} \mathrm{~cm}^{2} / \mathrm{s}-1,27 \times 10^{-6} \mathrm{~cm}^{2} / \mathrm{s}$ (Tsai et al., 2009). 


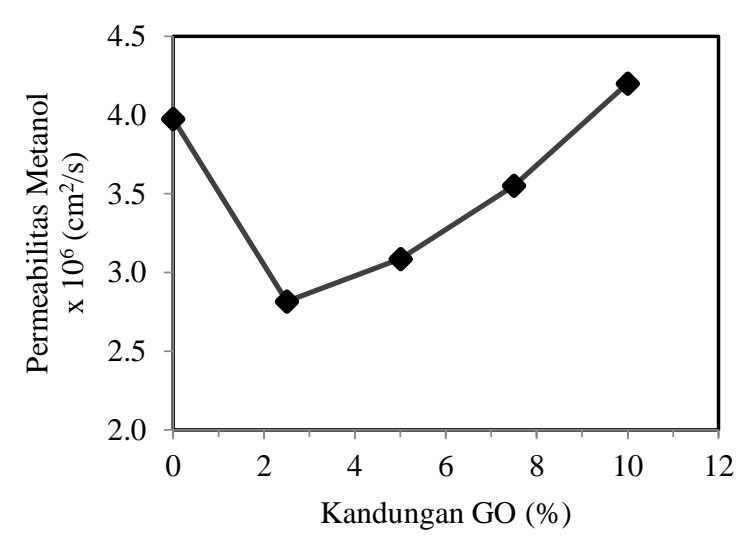

Gambar 3. Hubungan Permeabilitas metanol dengan persentase grafena oksida dalam membran sPEEK

\subsection{Kapasitas Penukar Ion}

Nilai kapasitas penukar ion dapat menjadi pertimbangan jumlah gugus ionik yang digunakan untuk transfer proton pada polimer. Kehadiran gugus ionik gugus sulfonat di dalam rantai polimer mengubah sifat kimia polimer yaitu menjadikan polimer lebih bersifat hidrofilik sehingga memudahkan transfer proton dalam membran (Hidayati et al., 2017). Gambar 4 menunjukkan hubungan antara kapasitas penukar ion dengan persentase grafena oksida dalam membran.

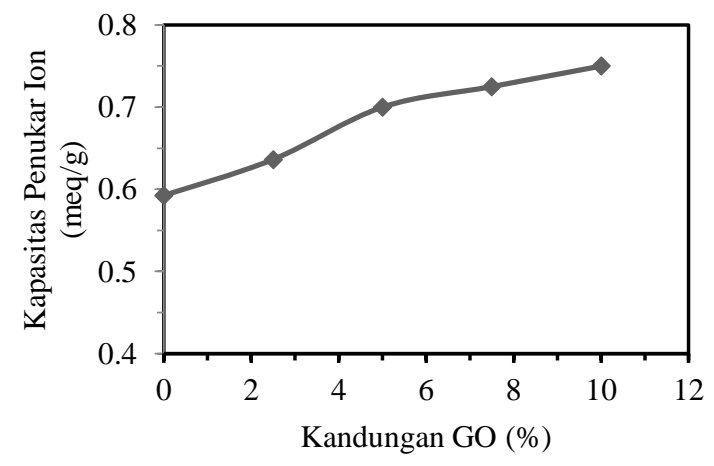

Gambar 4. Hubungan kapasitas penukar ion dengan persentase grafena oksida dalam membran sPEEK

Membran sPEEK-PVA dengan bahan isian menghasilkan nilai kapasitas penukar ion yang meningkat dari sekitar $0,59 \mathrm{meq} / \mathrm{g}$ menjadi sekitar $0,75 \mathrm{meq} / \mathrm{g}$ dari konsentrasi GO 0\%-10\%. Dari penelitian sebelumnya PVAkitosan grafena oksida menunjukkan nilai kapasitas ion paling besar pada konsentrasi grafena oksida 5\% sebesar $1,11 \mathrm{meq} / \mathrm{g}$ (Shaari and Kamarudin, 2018). Dapat diketahui bahwa peningkatan kapasitas penukar sebanding dengan penambahan jumlah grafena oksida yang berarti bahwa membran membran dapat mudah menghantarkan ion (konduktor). Meskipun perlu kajian lebih lanjut, membran sPEEK-PVA-GO layak dipertimbangkan sebagai membran untuk DMFC.

\section{Kesimpulan}

Membran komposit sPEEK-PVA dengan grafena oksida di dalamnya telah dibuat dan dikaji. Hasil karakterisasi menunjukkan bahwa water uptake, swelling degree, kapasitas penukar ion, dan permeabilitas metanol membran sPEEK-PVA dipengaruhi oleh banyaknya kandungan grafena oksida. Keberadaan PVA-GO dalam membran sPEEK membantu meningkatkan nilai kapasitas penukar ion membran sehingga memudahkan dalam menghantarkan ion (konduktor ion) yang lebih baik. Membran sPEEK-PVA dengan penambahan grafena oksida merupakan potensi yang baik untuk aplikasi sel bahan bakar metanol.

\section{Daftar Pustaka}

Ettihir, K., L. Boulon, and K. Agbossou, 2016, Optimization-Based Energy Management Strategy for a Fuel Cell/Battery Hybrid Power System, Applied Energy Vol.163: $142-53$. http://dx.doi.org/10.1016/j.apenergy.2015.10.176.

Guo, Chuigen, Lin Zhou, and Jianxiong Lv, 2013, Effects of Expandable Graphite and Modified Ammonium Polyphosphate on the Flame-Retardant and Mechanical Properties of Wood Flour-Polypropylene Composites, Polymers and Polymer Composites, Vol 21 No. 7: 44956.

Heo, Yuseon, Hyungu Im, and Jooheon Kim. 2013. The Effect of Sulfonated Graphene Oxide on Sulfonated Poly (Ether Ether Ketone) Membrane for Direct Methanol Fuel Cells. Journal of Membrane Science 425-426: 1122. http://dx.doi.org/10.1016/j.memsci.2012.09.019.

Hidayati, Nur et al., 2017, Sintesis Dan Karakteristik Membran Komposit Akrilonitril Butadiena Stirena ( ABS ) -Kitosan Tersulfonasi Untuk Direct Metanol Fuel Cell, Jurnal Matematika dan Sains, Vol.22: 20-23.

Hidayati, Nur, Muhammad Mujiburohman, Herry Purnama, and Muhammad Fahmi Hakim, 2015, Karakteristik Membran Komposit Poli Eter Eter Keton Tersulfonasi Untuk Direct Methanol Fuel Cell. Prosiding Seminar Nasional Teknik Kimia Kejuangan: L5-1-L5-7.

Kusworo, T D et al., 2013, Preparation of Poly Eter Eter Keton as Alternative Membrane for Direct Methanol Fuel Cell ( DMFC ), Advanced Membrane Technology Research Centre , Faculty of Chemical. Vol.18 No.9: 1240-52.

Mahajan, Chetan V, and Venkat Ganesan, 2010, Atomistic Simulations of Structure of Solvated Sulfonated Poly ( Ether Ether Ketone ) Membranes and Their Comparisons to Nafion: I . Nanophase Segregation and Hydrophilic Domains. : 8357-66.

Mahatmanti, F W et al. 2017, The Effect of Silane Addition on Chitosan-Fly Ash/CTAB as Electrolyte Membrane. IOP Conference Series: Materials Science and Engineering, Vol.172: 012016.

Matematika, Fakultas et al., 2015, Pengaruh Komposisi Terhadap Perilaku Membran Komposit PVA / Kitosan / Grafin Oksida Yang Terikat Silang Asam Sulfat, Vol 4 No.2: 2-6. 
Neburchilov, V, J Martin, H Wang, and J Zhang, 2007, A Review of Polymer Electrolyte Membranes for Direct Methanol Fuel Cells, Journal of Power Sources Vol.16 No.2: 221-38.

Rahman, Arief, Aprilina Purbasari, Tutuk Djoko, and Eniya Listiani. 2012, Composite SPEEK with Nanoparticles for Fuel Cell' s Applications : Review. : 1-11.

Reyes-Rodriguez, Jose Luis et al. 2017. Proton Conducting Electrospun Sulfonated Polyether Ether Ketone Graphene Oxide Composite Membranes, RSC Advances. Vol.7 No.84: 53481-91.

Sahin, Alpay., 2018, The Development of Speek/Pva/Teos Blend Membrane for Proton Exchange Membrane Fuel Cells. Electrochimica Acta, Vol.271: 127-36. https://doi.org/10.1016/j.electacta.2018.03.145.

Santosa, K., Malita, S., Mynaryasetya, dan Maksum. 2015. "Pengaruh Komposisi Terhadap Perilaku Membran
Komposit PVA / Kitosan / Grafin Oksida Yang Terikat Silang Asam Sulfat." Vol. 4 No.2: 2-6.

Shaari, N, and S K Kamarudin. 2018, Performance of Crosslinked Sodium Alginate / Sulfonated Graphene Oxide as Polymer Electrolyte Membrane in DMFC Application: RSM Optimization Approach, International Journal of Hydrogen Energy, https://doi.org/10.1016/j.ijhydene.2018.10.098.

Tsai, Jie-cheng et al. 2009, Blended Nafion ® / SPEEK Direct Methanol Fuel Cell Membranes for Reduced Methanol Permeability, Vol.189: 958-65.

Yang, Tao. 2008. Preliminary Study of SPEEK / PVA Blend Membranes for DMFC Applications. International Journal of Hydrogen Energy, Vol.33 No.22: 6772-79. http://dx.doi.org/10.1016/j.ijhydene.2008.08.022 